\title{
KARAKTERISTIK MUTU BUBUK OKARA HASIL KERAGAMAN PERLAKUAN HIDROTERMAL DAN SUHU PENGERINGAN
}

\section{Quality Characteristics of Okara Powder Produced Under a Variety of Hydrothermal} Treatments and Drying Temperatures

\author{
Iwan Taruna ${ }^{1) *}$ \\ 1)Jurusan Teknik Pertanian, Fakultas Teknologi Pertanian, Universitas Jember \\ Jalan Kalimantan 37 Kampus Tegal Boto Jember 68121 \\ *Korespondensi Penulis: taruna@unej.ac.id
}

\begin{abstract}
The present study aimed to investigate the influences of experimental variables, i.e. hydrothermal treatments (whithout and treated) and convective drying temperatures $\left(70,80\right.$ and $\left.90^{\circ} \mathrm{C}\right)$ on the quality characteristics of okara powders. The quality parameters of the okara powder studied in this experiment consisted of color attributes, particle density, water absorption capacity, oil absorption capacity, $p H$, viscosity, and non-enzymatic browning. The results showed that the quality of okara powders varied depending on the experimental variables. Hydrothermal treatment and drying of okara at lower temperatures could increase the brightness ( $L$ value) from 62.37 to 70.23 , and increased the $b$ value of okara powder color from 43.65 to 49.16 . However, the particle density $\left(1.04-1.35 \mathrm{~g} / \mathrm{cm}^{3}\right)$ and $\mathrm{pH}$ value (6.48-6.78) of okara powders were not significantly affected by hydrothermal treatment. The okara powder solution with hydrothermal treatment $(2.10-4.50 \mathrm{cP})$ showed a lower average viscosity value compared to okara powder without hydrothermal treatment ((2.60-4.80 cP). The study also concluded that okara powder absorbed significantly more water rather than absorbing oil, as indicated by the value of water absorption capacity $(4.7-5.7 \mathrm{~mL} / \mathrm{g})$, which greater than oil absorption capacity (1.1-1.4 mL/g). Non-enzymatic browning occurrence on okara powder samples $(O D=0.52$ 0.66) was more affected by the drying temperature than hydrothermal treatment.
\end{abstract}

Keywords: convective drying, hydrothermal treatment, okara powder quality

\section{PENDAHULUAN}

Peningkatan jumlah kasus penyakit degeneratif pada generasi muda telah mendorong transformasi pola konsumsi masyarakat masa kini menjadi lebih peduli pada pangan berkalori rendah dan berserat tinggi. Fenomena ini akan memerlukan sumber-sumber pangan alternatif yang memenuhi kriteria tersebut. Salah satu bahan kaya serat dan rendah kalori yang cocok dengan kriteria tersebut adalah okara atau ampas tahu, yaitu limbah agoindustri tahu dan susu kedelai. Walaupun tergolong sebagai limbah, okara masih bermuatan nutrisi penting bagi manusia seperti serat, protein, lemak dan nutrisi lainnya seperti asam amino (Li et al., 2012; Zhong and Zhao, 2016). Ma et al. (1997) telah menunjukkan bahwa beberapa sifat fungsional isolat protein okara masih bermutu tinggi dan setara dengan kandungan isolat protein kedelai komersial. Oleh sebab itu, pengembangan okara menjadi produk "siap pakai" untuk bahan baku maupun bahan tambahan pada berbagai olahan pangan harus diupayakan agar dapat meningkatkan fungsi dan nilai ekonominya.

Salah satu metode pemanfaatan okara paling praktis dan ekonomis untuk bahan olahan pangan adalah mengkonversinya menjadi produk bubuk okara. Beberapa studi terdahulu membuktikan bahwa bubuk okara dapat diaplikasikan pada beragam produk pangan antara lain beef patties, mie, roti kukus dan kue kering (cookies) (Turhan et al., 2009; Lu et al., 2013; Porcel et al., 2017). Tahapan awal produksi bubuk okara 
biasanya berupa proses pengeringan okara yang akan memudahkan penanganan dan pengolahan lebih lanjut. Namun demikian, proses pengeringan bahan biologis seperti ini biasanya menghadapi masalah klasik yakni terjadinya perubahan mutu produk akhir yang tergantung pada keragaman metode dan kondisi pengeringan, aktivitas air dan waktu. Keragaman mutu tersebut meliputi perubahan fisik, struktur, dan kandungan kimia didalamnya. Perusello et al. (2009) telah mendemonstrasikan bahwa kenaikan suhu pengeringan okara secara konveksi mendegradasi tingkat kecerahan warnanya. Variasi kondisi pengeringan okara menggunakan spouted-vortex bed dryer mempengaruhi warna, densitas partikel, kapasitas penyerapan air dan minyak bubuk okara (Taruna, 2006). Berdasarkan uraian tersebut tampak bahwa kajian lebih lanjut mengenai pengaruh metode penanganan awal, tipe dan kondisi pengeringan pada perubahan-perubahan mutu yang terjadi selama dan sesudah proses pengeringan okara masih sangat perlu dilakukan dalam rangka menemukan metode dan kondisi pengolahan yang optimal untuk menghasilkan bubuk okara bermutu tinggi. Oleh karena itu, tujuan riset ini adalah mengkaji pengaruh penanganan pra perlakuan hidrotermal, dan suhu pengeringan okara terhadap mutu produk bubuk okara yang dihasilkan. Parameter mutu bubuk okara yang dievaluasi dalam studi ini terdiri dari atribut warna, densitas partikel, kapasitas penyerapan air dan penyerapan minyak, nilai $\mathrm{pH}$, viskositas dan pencokalatan non enzimatik.

\section{METODE PENELITIAN}

\section{Alat dan Bahan}

Peralatan yang digunakan dalam studi ini adalah colour reader (Konica Minolta CR-10), autoclave, alat pengepres, unit pengering konveksi, baki stainles steel, eksikator, oven (Memmert, model UNB 400), pengayak (60 mesh), sentrifuge (Gemmy PLC-05), test tube, $\mathrm{pH}$ meter
(Phionlab PC10), viscometer (Brookfield DVII+Pro), spektrofotometer (LaMotte Smart Spectro).

Bahan yang digunakan dalam studi ini adalah okara (ampas tahu) yang berasal dari limbah pembuatan tahu berdasarkan metode Shurtleff and Aoyagi (2000). Okara yang diperoleh lalu dibagi menjadi dua bagian, yaitu bagian pertama dibebaskan tanpa pra perlakuan (diberi simbol OR), sedangkan bagian yang kedua mendapat perlakuan hidrotermal (diberi simbol HT) berupa pengukusan dalam autoclave pada suhu $100^{\circ} \mathrm{C}$ selama 20 menit. Cara pra perlakuan tersebut merupakan modifikasi metode yang diadopsi dari Lu and Jasser (1986). Kedua jenis sampel okara tersebut selanjutnya digunakan untuk percobaan pengeringan okara.

\section{Tahapan Penelitian}

\section{Pembuatan Bubuk Okara}

Bahan okara yang diperoleh melalui pra perlakuan HT maupun OR, awalnya didehidrasi secara mekanis menggunakan alat pengepres. Kadar air awal okara lalu diukur dengan metode gravimetri (AOAC, 1999). Setelah itu, sejumlah \pm 1000 g okara diletakkan pada beberapa baki stainless steel berperforasi dengan ketebalan 15-20 $\mathrm{mm}$, dan dikeringkan di dalam unit pengering konveksi pada suhu 70, 80 dan $90^{\circ} \mathrm{C}$. Laju udara pengeringan dijaga pada $\pm 1,5 \mathrm{~m} / \mathrm{s}$ selama pengeringan, hingga proses distop pada saat kadar air okara mencapai 5,0-6,0\% basis basah. Okara hasil pengeringan kemudian direduksi ukuran partikelnya, dan diayak hingga diperoleh bubuk okara dengan ukuran partikel $\leq 60$ mesh. Sampel bubuk okara tersebut dikemas dalam plastik dan diletakkan dalam eksikator pada suhu ruang agar stabil kelembabannya sebelum dievaluasi mutunya.

\section{Rancangan Percobaan}

Penelitian dilaksanakan berdasarkan metode rancangan acak lengkap (RAL) faktorial $2 \times 3$. Faktor I adalah perlakuan 
hidrotermal okara terdiri dari 2 level yaitu HT dan OR. Faktor II merupakan suhu pengeringan okara terdiri dari 3 level yaitu 70,80 dan $90^{\circ} \mathrm{C}$. Jumlah ulangan untuk setiap kombinasi perlakuan adalah tiga kali.

Data-data hasil percobaan dari setiap perlakuan diolah menggunakan aplikasi SPSS 14.0 untuk mengevaluasi korelasi antara variabel percobaan (pra perlakuan hidrotermal dan suhu pengeringan) dengan parameter mutu bubuk okara. Pengujian derajat signifikan rerata data eksperimen dilakukan pada level signifikan yang ditetapkan sebesar $\alpha=0,05$.

\section{Metode Analisis}

Evaluasi mutu sampel bubuk okara yang dihasilkan dari beragam kondisi percobaan ditentukan berdasarkan parameter atribut warna (L, a dan b), densitas partikel $\left(\rho_{\mathrm{p}}\right)$, kapasitas penyerapan air (KPA), kapasitas penyerapan minyak (KPM), $\mathrm{pH}$, viskositas $(\mu)$ dan pencokalatan non enzimatik (OD). Prosedur penentuan nilai-nilai parameter mutu tersebut adalah sebagai berikut:

\section{Atribut Warna}

Warna sampel bubuk okara diukur menggunakan unit colour reader (Konica Minolta, CR-10) berdasarkan pada sistem Hunter Lab. Menurut Hunter Lab (2008), nilai L menunjukkan lightness atau sifat terang dan gelap warna tepung okara dalam rentang nilai 0-100 (hitam-putih), sedangkan parameter a dan $b$ tidak memiliki rentang nilai spesifik. Namun demikian, nilai -a menggambarkan warna hijau dan +a menunjukkan warna merah, sedangkan nilai -b menunjukkan warna biru, dan $+b$ merepresentasikan warna kuning. Pembacaan atribut warna pada sampel tepung okara dilakukan pada lima posisi yang berbeda pada setiap permukaan sampel.

\section{Densitas Partikel ( $\left.\rho_{p}\right)$}

Densitas partikel $\left(\rho_{\mathrm{p}}\right)$ bubuk okara ditentukan berdasarkan metode liquid displacement menggunakan media cairan kerosene pada piknometer seperti yang dijabarkan Mohsenin (1986).

\section{Kapasitas Penyerapan Air (KPA)}

Kapasitas penyerapan air (KPA) bubuk okara diukur menggunakan modifikasi metode dari Traina and Breene (1994). Sekitar 1,1-1,4 g bubuk okara dicampur dengan $10 \mathrm{~mL}$ aquades di dalam test tube, dikocok selama 1 menit dan lalu didiamkan \pm 30 menit pada suhu ruang $\left( \pm 25^{\circ} \mathrm{C}\right)$. Test tube kemudian disentrifugasi pada 2000 rpm selama 25 menit. Nilai KPA dihitung berdasarkan jumlah air yang tertahan pada sampel tepung setelah penirisan.

\section{Kapasitas Penyerapan Minyak (KPM)}

Nilai kapasitas penyerapan minyak (KPM) ditentukan dengan cara yang serupa dengan penentuan KPA, kecuali mengganti aquades dengan $3 \mathrm{~mL}$ minyak kelapa sawit.

\section{Nilai $p H$}

Nilai $\mathrm{pH}$ bubuk okara ditentukan menggunakan metode dari Egan et al. (1987), yaitu sekitar 10-12 g dicampur dengan $100 \mathrm{~mL}$ aquades dan dikocok hingga terlarut sempurna. Setelah itu larutan didiamkan 30 menit, lalu difiltrasi untuk memperoleh filtrat yang diukur $\mathrm{pH}$ nya dengan alat $\mathrm{pH}$ meter digital (Phionlab Model PC10).

\section{Viskositas $(\mu)$}

Viskositas $(\mu)$ suspensi bubuk okara diukur dengan cara menggabungkan metode oleh Lu and Jasser (1986) dan Traina and Breene (1994). Suspensi okara yang dibuat dari campuran $20 \mathrm{~g}$ bubuk okara dan $380 \mathrm{~mL}$ aquades, diaduk dengan unit mixer selama 5 menit dan kemudian diukur viskositasnya pada suhu ruang $\left(25^{\circ} \mathrm{C}\right)$ menggunakan alat Brookfield Viscometer DVII+Pro yang dioperasikan menggunakan spindle nomor 1 atau 2 pada putaran $60 \mathrm{rpm}$. Data viskositas diambil setelah spindel berputar tepat 10 detik. 
Penentuan Pencoklatan Non Enzimatik (OD)

Penentuan pencoklatan non enzimatik (OD) yang terjadi pada bubuk okara dilakukan berdasarkan metode dari Askar and Treptow (1993). Sekitar $10 \mathrm{~g}$ sampel dicampur dengan $100 \mathrm{~mL}$ etanol $60 \%$, kemudian diekstraksi selama 12 jam. Setelah itu, larutan disentrifugasi pada 300 rpm selama 5 menit. Nilai OD (optical density) ekstrak bubuk okara diukur dengan spektrofotometer pada $420 \mathrm{~nm}$ terhadap $60 \%$ etanol.

\section{HASIL DAN PEMBAHASAN}

\section{Karakteristik Mutu Bubuk Okara}

Nilai korelasi variabel percobaan dengan parameter mutu bubuk okara dapat dilihat pada Tabel 1. Secara umum, suhu pengeringan menunjukkan korelasi yang lebih nyata dengan parameter mutu bubuk okara yang tanpa perlakuan hidrotermal (OR) daripada okara dengan pra perlakuan hidrotermal (HT). Hal ini mengindikasikan bahwa pra perlakuan hidrotermal okara sebelum pengeringan dapat mengurangi sensitivitas sampel terhadap pengaruh suhu pengeringan. Tabel 1 menunjukkan bahwa nilai korelasi suhu pengeringan dengan mutu bubuk okara pada kolom perlakuan HT relatif lebih kecil daripada okara OR. Meskipun suhu pengeringan menunjukkan korelasi yang kuat dengan nilai KPA bubuk okara HT $(\mathrm{r}=-0,605)$, namun secara statistik tidak signifikan baik pada $\alpha \leq 0,01$ maupun 0,05 .
Tabel 1. Korelasi (r) antara variabel percobaan dan parameter mutu bubuk okara

\begin{tabular}{|c|c|c|}
\hline \multirow{2}{*}{ Parameter mutu } & \multicolumn{2}{|c|}{ Suhu pengeringan } \\
\hline & HT & OR \\
\hline $\mathrm{L}$ & $-0,961^{* * *}$ & $-0,972^{* *}$ \\
\hline $\mathrm{a}$ & $0,885^{* *}$ & $0,570^{* *}$ \\
\hline $\mathrm{b}$ & $-0,959^{* *}$ & $-0,969^{* *}$ \\
\hline$\rho_{\mathrm{p}}\left(\mathrm{g} / \mathrm{cm}^{3}\right)$ & 0,095 & $-0,116$ \\
\hline $\mathrm{KPA}(\mathrm{mL} / \mathrm{g})$ & $-0,605$ & $-0,907^{* *}$ \\
\hline $\mathrm{KPM}(\mathrm{mL} / \mathrm{g})$ & $-0,065$ & $-0,032$ \\
\hline $\mathrm{pH}$ & $-0,158$ & 0,427 \\
\hline Viskositas (cP) & $-0,895^{* *}$ & $-0,986^{* *}$ \\
\hline OD & $0,901^{* *}$ & $0,954^{* *}$ \\
\hline \multicolumn{3}{|c|}{ *** signifikan pada $\alpha \leq 0,01$} \\
\hline \multicolumn{3}{|c|}{$\begin{array}{ll}\text { Keterangan: } & \mathrm{L}=\text { lightness } \quad \mathrm{a}=\text { redness } \\
\mathrm{b}=\text { yellowness } \quad \rho_{\mathrm{p}}=\text { densitas partikel } \\
\mathrm{KPA}=\text { kapasitas penyerapan air } \\
\mathrm{KPM}=\text { kapasitas penyerapan minyak } \\
\mathrm{OD}=\text { optical density }\end{array}$} \\
\hline
\end{tabular}

\section{Atribut Warna}

Profil hubungan suhu pengeringan dengan atribut warna L, a, dan b bubuk okara ditunjukkan pada Gambar 1-3 untuk beragam pra perlakuan hidortermal. Nilai L, a dan b bubuk okara hasil eksperimen ini menunjukkan nilai bervariasi, yaitu nilai $\mathrm{L}$ $=62,37-70,23, a=4,38-7,80$ dan $b=43,65$ 49,16 tergantung pada suhu pengeringan dan pra perlakuan hidrotermal. Korelasi suhu pengeringan dengan atribut warna bubuk okara menunjukkan nilai negatif, kecuali untuk nilai a yang menunjukkan korelasi positif. Nilai L warna bubuk okara menurun saat suhu pengeringan meningkat dari 70 ke $90^{\circ} \mathrm{C}$. Korelasi antara suhu pengeringan dengan nilai $\mathrm{L}$ sangat kuat dan signifikan, yakni $r=-0,961$ untuk sampel dengan perlakuan HT dan $\mathrm{r}=-0,969$ untuk perlakuan OR. Seperti telah diduga bahwa pengeringan okara pada suhu yang lebih rendah meningkatkan tingkat kecerahan warna bubuk okara. 


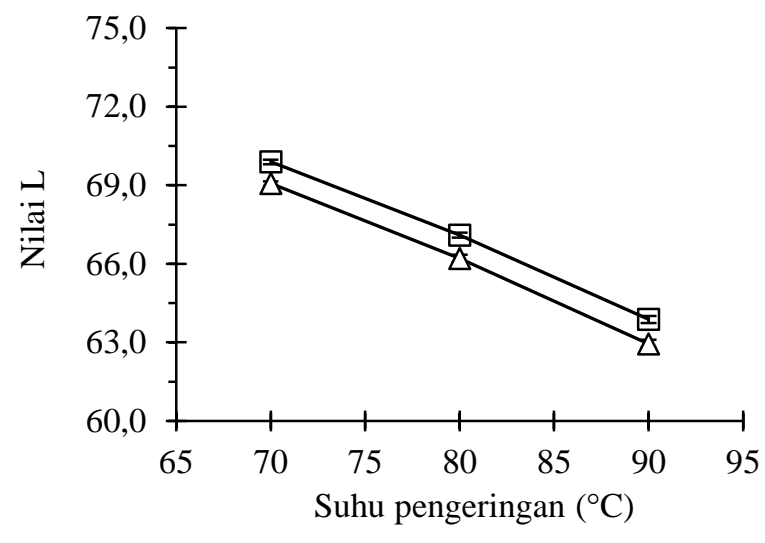

Gambar 1. Hubungan suhu pengeringan dengan nilai $L$ bubuk okara untuk perlakuan OR $(\boldsymbol{\Delta})$ dan HT (מ-)

Gambar 1 juga telah memperlihatkan bahwa nilai L bubuk okara dengan perlakuan HT lebih tinggi daripada perlakuan OR, sehingga aplikasi perlakuan hidrotermal sebelum pengeringan okara ternyata memperbaiki tingkat kecerahan warna bubuk okara. Fenomena ini sejalan dengan pernyataan Perussello et al. (2009) bahwa proses pengeringan okara pada suhu tinggi menyebabkan penampakan okara kering menjadi semakin gelap. Perubahan sifat permukaan okara akibat pengeringan suhu tinggi diduga mengurangi kapasitas memantulkan cahaya yang berperan sangat vital menentukan kecerahan warna bahan. Korelasi nilai a bubuk okara dengan suhu pengeringan adalah signifikan, baik untuk okara HT $(\mathrm{r}=0,885)$ maupun OR $(\mathrm{r}=$ 0,570). Nilai a meningkat seiring dengan kenaikan suhu pengeringan okara, sehingga secara visual cenderung menunjukkan kesan kemerahan.

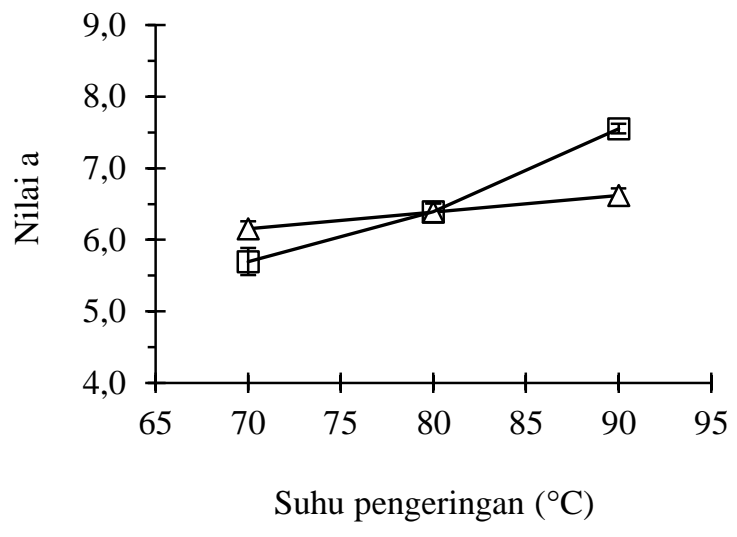

Gambar 2. Hubungan suhu pengeringan dengan nilai a warna bubuk okara untuk perlakuan OR $(\boldsymbol{\Delta}-)$ dan HT (-

Gambar 2 memperlihatkan bahwa pra perlakuan hidrotermal okara (HT) sebelum pengeringan meningkatkan laju perubahan nilai a bubuk okara pada rentang suhu pengeringan $70-90^{\circ} \mathrm{C}$. Nilai gradien tren perubahan nilai a bubuk okara HT yang lebih besar daripada okara OR menjadi bukti fenomena tersebut. Namun demikian, peningkatan nilai a bubuk okara dengan pra perlakuan HT sangat kecil yaitu dengan selisih $\pm 1,8$ untuk rentang suhu dari 70 hingga $90^{\circ} \mathrm{C}$. Korelasi suhu pengeringan dengan nilai $\mathrm{b}$ bubuk okara menunjukkan kemiripan dengan nilai L, yakni berkorelasi negatif dan signifikan baik untuk perlakuan $\mathrm{HT}(\mathrm{r}=-0,959)$ maupun perlakuan OR $(\mathrm{r}=$ $-0,959)$.

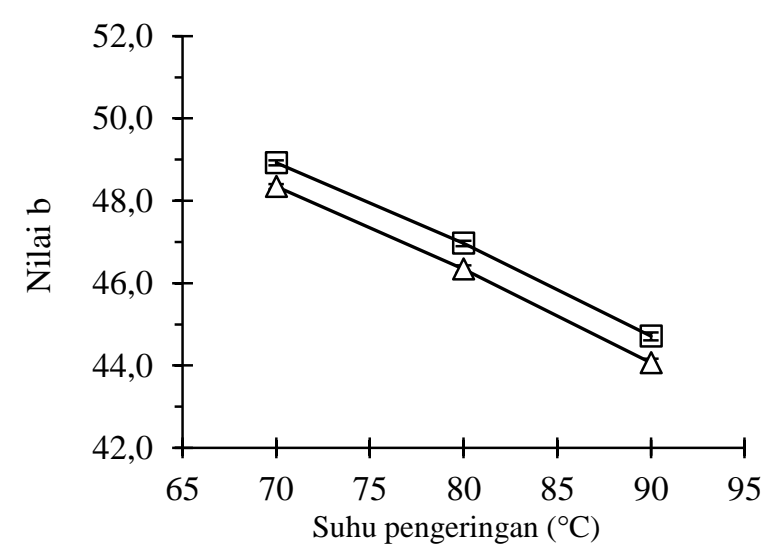

Gambar 3. Hubungan suhu pengeringan dengan nilai b warna bubuk okara untuk perlakuan OR ( $-\boldsymbol{\Delta})$ dan HT (מח) 
Gambar 3 memperlihatkan bahwa peningkatan suhu pengeringan dari $70 \mathrm{ke}$ $90^{\circ} \mathrm{C}$ menurunkan nilai b bubuk okara. Hal ini bermakna bahwa peningkatan suhu pengeringan okara menurunkan kesan warna kuning pada warna bubuk okara, sehingga secara logis berkontribusi pada penurunan tingkat kecerahan warna bubuk okara. Fenomena serupa telah dilaporkan sebelumnya oleh Taruna dan Astuti (2018), bahwa pengeringan konveksi okara pada suhu lebih tinggi menurunkan nilai $L$ dan $b$ okara, akan tetapi meningkatkan nilai a okara. Namun demikian, studi menemukan bahwa perlakuan hidrotermal (HT) okara meningkatkan nilai b bubuk okara.

\section{Densitas Partikel}

Densitas partikel $\left(\rho_{\mathrm{p}}\right)$ bubuk okara bervariasi dalam rentang 1,04-1,35 $\mathrm{g} / \mathrm{cm}^{3}$ tergantung pada pra perlakuan hidrotermal okara sebelum pengeringan, seperti dapat dilihat Gambar 4. Korelasi nilai densitas partikel dengan suhu pengeringan sangat lemah dan tidak signifikan, yaitu $r=-0,116$ untuk okara HT dan $r=0,095$ untuk okara OR. Meskipun hubungan antara densitas partikel dengan suhu pengeringan relatif tidak dapat didefinisikan, namun bubuk okara dengan perlakuan hidrotermal (HT) menunjukkan nilai relatif lebih rendah daripada tanpa perlakuan hidrotermal (OR). Kejadian ini patut diduga disebabkan oleh terjadinya retakan karena perlakuan termal, dan adanya permukaan tak beraturan pada bahan berserat tinggi seperti okara, yang berpengaruh pada densitas partikel seperti telah dilaporkan sebelumnya oleh Chang and Morris (1990).

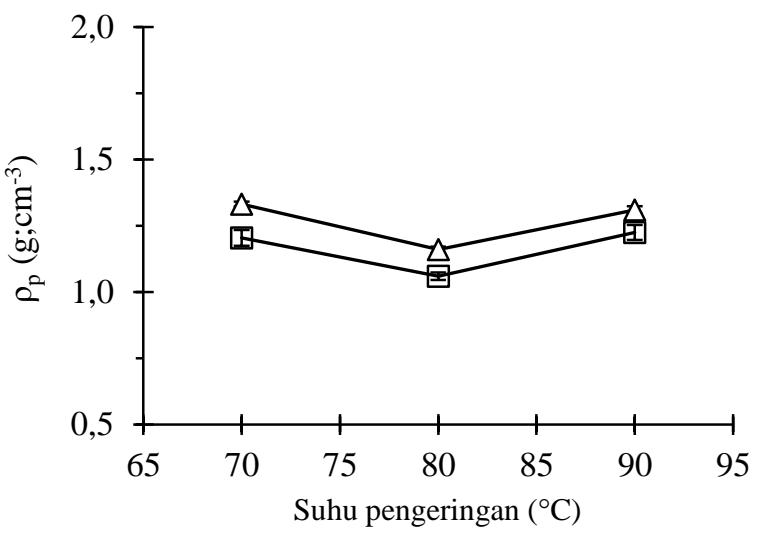

Gambar 4. Hubungan suhu pengeringan dengan densitas partikel bubuk okara untuk perlakuan OR ( $\boldsymbol{( \boldsymbol { L }})$ dan HT (מט)

\section{Kapasitas Penyerapan Air}

Dalam studi ini, kapasitas penyerapan air (KPA) bubuk okara berkisar antara 4,7 hingga $5,7 \mathrm{~mL} / \mathrm{g}$ tergantung pada kondisi percobaan. Nilai-nilai KPA tersebut identik dengan KPA bubuk okara yang dihasilkan menggunakan pengeringan microwave dan rotary dryer sebagaimana dilaporkan dalam Porcel et al. (2017). Peningkatan suhu pengeringan okara cenderung menurunkan KPA bubuk okara seperti ditunjukkan pada Gambar 5. Penurunan KPA bahan pada umumnya disebabkan oleh perlakuan panas yang menurunkan elastisitas dinding sel dan memfasilitasi koagulasi protein. Oleh sebab itu, bubuk okara dengan perlakuan HT menunjukkan nilai KPA lebih rendah dibandingkan nilai KPA tanpa perlakuan hidrotermal (OR). Korelasi antara suhu pengeringan dengan nilai KPA bubuk okara adalah kuat dan tidak signifikan untuk okara HT, tetapi sangat kuat dan signifikan untuk okara OR. Karena itu, pra perlakuan hidrotermal okara sebelum pengeringan relatif dapat menjaga stabilitas nilai KPA bubuk okara meskipun suhu pengeringan dinaikkan dari 70 ke $90^{\circ} \mathrm{C}$. 


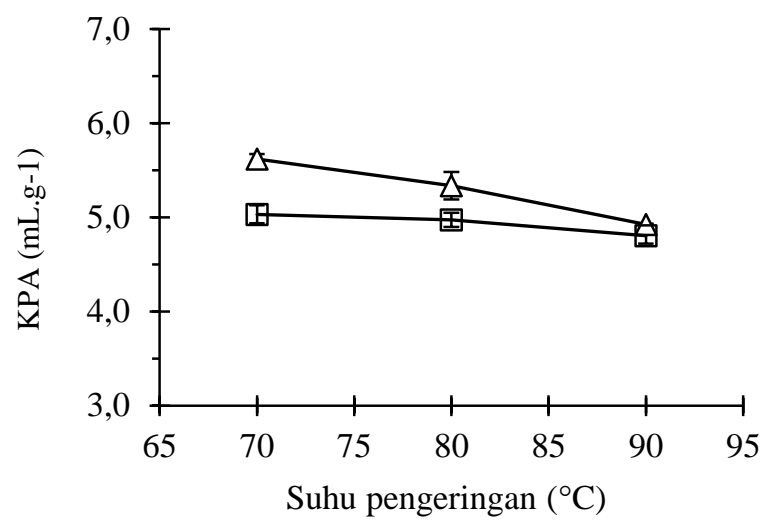

Gambar 5. Hubungan suhu pengeringan dengan kapasitas penyerapan air bubuk okara untuk perlakuan OR $(\boldsymbol{\Delta}-)$ dan HT (므)

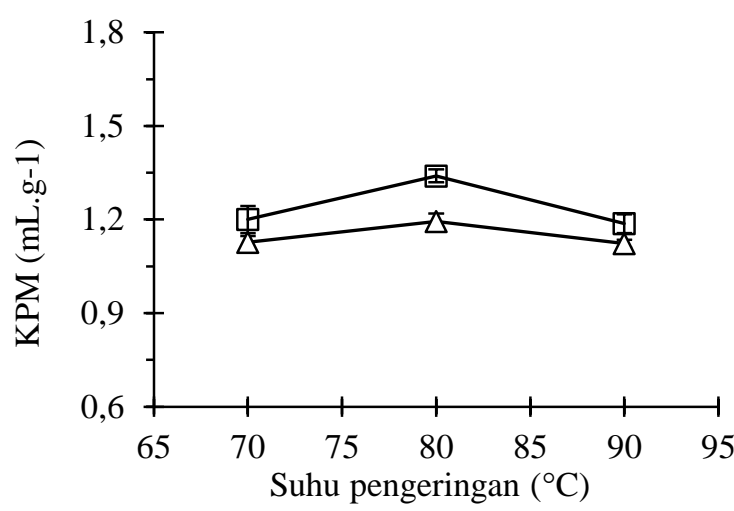

Gambar 6. Hubungan suhu pengeringan dengan kapasitas penyerapan minyak bubuk okara untuk perlakuan OR $(-\boldsymbol{\Delta}-)$ dan HT (מח)

\section{Kapasitas Penyerapan Minyak}

Kapasitas penyerapan minyak (KPM) bubuk okara sebagai fungsi dari suhu pengeringan dan perlakuan hidrotermal ditunjukkan pada Gambar 6. Nilai KPM bubuk okara dalam studi ini bervariasi pada kisaran 1,1-1,4 mL/g dan menampakkan kecenderungan yang tidak jelas seiring dengan perubahan suhu pengeringan okara. Kenyataan ini relevan dengan rendahnya nilai korelasi yang ditunjukkan antara suhu pengeringan dengan nilai KPM seperti dicantumkan pada Tabel 1, yaitu $r=-0,065$ . untuk okara HT dan $r=-0,032$ untuk okara tanpa perlakuan hidrotermal (OR). Namun demikian, penerapan perlakuan hidrotermal okara (HT) sebelum pengeringan konveksi ternyata meningkatkan kemampuan bubuk okara dalam menyerap minyak seperti diperlihatkan pada Gambar 6. Penyerapan minyak oleh bahan mengandung protein seperti halnya produk berbasis kedelai umumnya dikaitkan dengan jebakan fisik lemak oleh protein yang terdapat dalam bahan tersebut. Nguyen et al. (2015) telah membuktikan bahwa tambahan perlakuan berupa tekanan uap panas pada proses produksi bubuk kedelai telah meningkatkan kemampuan penyerapan minyak bubuk kedelai dibandingkan cara konvensional. Fenomena yang sama patut diduga terjadi pada produk bubuk okara yang dikaji dalam studi ini

\section{Viskositas}

Hasil penentuan viskositas suspensi bubuk okara dalam studi ini diilustrasikan pada Gambar 7, dan menunjukkan rentang nilai $2,10-4,80 \mathrm{cP}$ tergantung pada variabel percobaan yaitu perlakuan hidrotermal dan suhu pengeringan okara. Sifat korelasi suhu pengeringan dengan viskositas sangat kuat dan signifikan, baik untuk okara HT ( $\mathrm{r}=$ $0,895)$ maupun okara OR $(\mathrm{r}=-0,986)$. Hasil observasi menunjukkan bahwa peningkatan suhu pengeringan okara menurunkan nilai viskositas suspensi bubuk okara. Selain itu, pra perlakuan hidrotermal (HT) pada okara menyebabkan penurunan nilai viskositas suspensi bubuk okara. Kedua fenomena ini dapat dipahami karena adanya denaturasi protein okara sebagai akibat dari adanya perlakuan panas dalam bentuk peningkatan suhu pengeringan dan tambahan perlakuan hidrotermal pada okara. Protein okara yang terdenaturasi akan menurun kelarutannya sehingga mempengaruhi nilai viskositas. Karakteristik tersebut serupa dengan hasil studi Benoit et al. (2013) pada produk whey protein concentrate, dimana peningkatan temperatur dari $20 \mathrm{ke} 60^{\circ} \mathrm{C}$ menurunkan viskositas whey protein concentrate dari 3,3 ke $1,3 \mathrm{cP}$. 


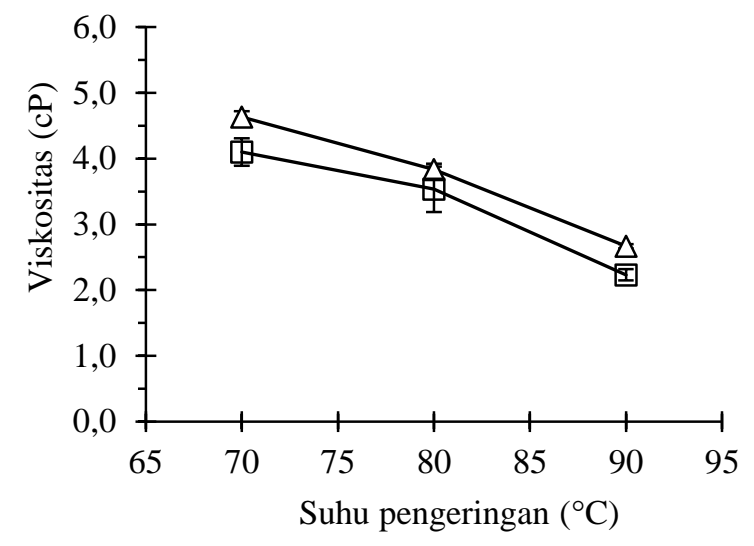

Gambar 7. Hubungan suhu pengeringan dengan viskositas suspensi bubuk okara untuk perlakuan OR $(\boldsymbol{-}-)$ dan HT (-)

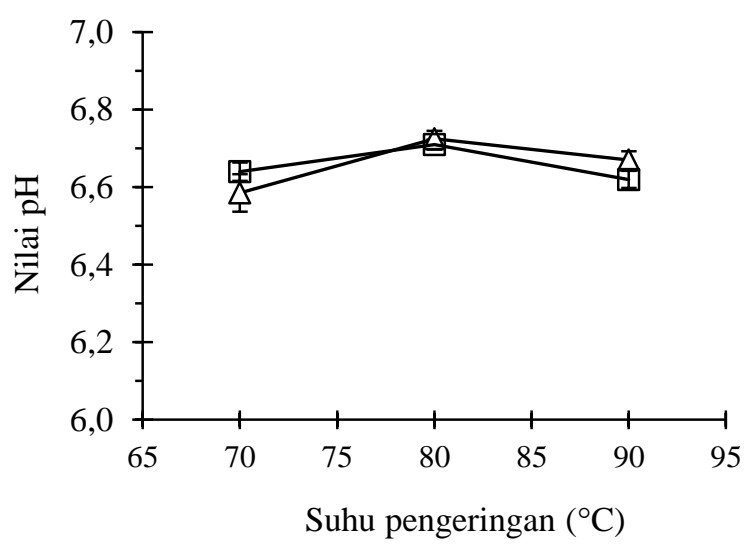

Gambar 8. Hubungan suhu pengeringan dengan nilai $\mathrm{pH}$ filtrat ekstraksi bubuk okara untuk perlakuan OR $(\boldsymbol{-}-\mathbf{-})$ dan HT (-口)

\section{Nilai $p H$}

Pengukuran $\mathrm{pH}$ filtrat hasil ekstraksi bubuk okara menghasilkan rentang nilai 6,48-6,78 seperti ditunjukkan Gambar 8. Kisaran nilai $\mathrm{pH}$ ini berada pada selang nilai antara 6,0 hingga 6,8 seperti yang dilaporkan oleh Egan et al. (1987). Tampak pada Gambar 8 bahwa mayoritas nilai $\mathrm{pH}$ sampel bubuk okara secara statistik tidak menunjukkan perbedaan yang nyata satu sama lain. Hal ini diperkuat dengan hasil korelasi nilai $\mathrm{pH}$ dengan suhu pengeringan pada Tabel 1, yang menunjukkan korelasi negatif, sangat lemah dan tidak signifikan untuk okara HT $(r=-0,158)$, serta korelasi bersifat negatif, cukup dan tidak signifikan untuk okara OR $(r=-0,427)$. Kejadian ini memberikan indikasi bahwa setiap sampel bubuk okara yang dihasilkan dalam studi ini memiliki kemiripan kandungan protein terlarut. Hubungan antara nilai $\mathrm{pH}$ dengan prosentase protein terlarut dalam okara telah dijelaskan dalam Ma et al. (1997).

\section{Pencoklatan non enzimatik}

Pencoklatan non enzimatik atau nonenzymatic browning, umumnya dianggap sebagai faktor utama penyebab kerusakan warna pangan karena diproses panas (suhu tinggi) atau disimpan dalam jangka waktu lama. Penilaian level browning pada sebuah bahan biasanya dinyatakan dengan nilai OD (optical density) dari filtrat larutan produk yang dibaca menggunakan alat spektrofotometer pada $420 \mathrm{~nm}$. Hasil penentuan nilai browning bubuk okara dalam riset ini disajikan pada Gambar 9, yang berkisar dari 0,52 hingga 0,66 baik untuk okara HT dan OR. Suhu pengerigan okara berkorelasi positif sangat kuat dan signifikan dengan nilai viskositas suspensi bubuk okara baik untuk okara HT ( $\mathrm{r}=$ $0,901)$ dan okara OR $(r=0,954)$. Kenyataan ini membuktikan bahwa nilai OD suspensi bubuk okara baik yang mendapat perlakuan HT dan OR semakin meningkat dengan kenaikan suhu pengeringan okara. Namun demikian, Gambar 9 juga menampakkan dua hal yang spesifik yakni: 1) peningkatan browning okara karena suhu pengeringan terjadi secara nyata hanya pada selang suhu $77-90^{\circ}$, dan 2) pra perlakuan hidrotermal pada okara (HT) relatif dapat menurunkan nilai browning selama pengeringan. Selain itu, nilai browning bubuk okara dalam studi ini terbukti relevan dengan karakteristik tingkat kecerahan warna (L) bubuk okara, dimana kedua parameter mutu tersebut menunjukkan tren korelasi yang saling berlawanan terhadap suhu pengeringan. 


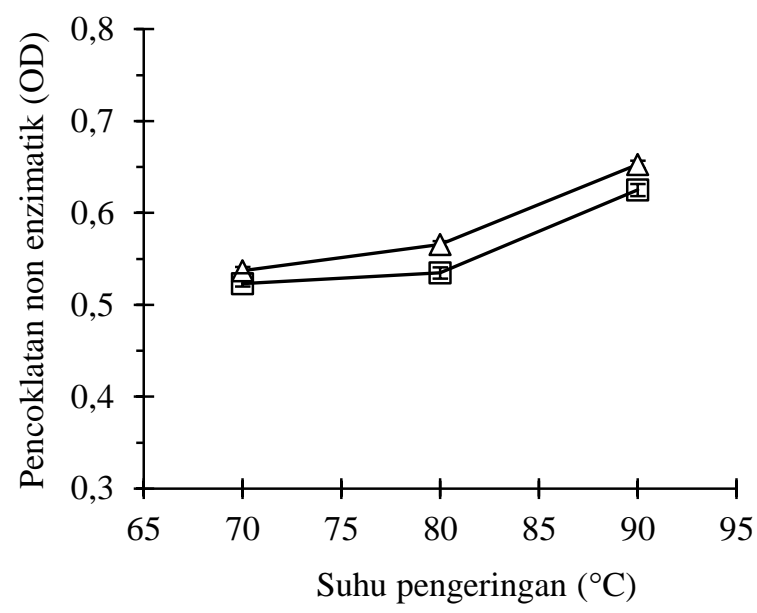

Gambar 9. Hubungan suhu pengeringan dengan nilai OD pencoklatan warna bubuk okara untuk perlakuan OR $(\boldsymbol{-} \boldsymbol{-})$ dan HT (ص)

\section{KESIMPULAN}

Kesimpulan yang dapat diambil dari penelitian ini yaitu bahwa pra perlakuan hidrotermal pada okara dan variasi suhu pengeringan okara menunjukkan pengaruh yang bervariasi pada karakteristik mutu bubuk okara yang meliputi warna, densitas partikel, KPA, KPM, nilai $\mathrm{pH}$, viskositas dan browning. Perlakuan hidrotermal pada okara dan proses pengeringan okara dengan suhu lebih rendah dapat meningkatkan nilai $\mathrm{L}$ dan nilai $\mathrm{b}$ warna bubuk okara. Densitas partikel dan nilai $\mathrm{pH}$ bubuk okara tidak secara signifikan dipengaruhi oleh adanya pra-perlakuan hidrotermal okara sebelum pengeringan, sedangkan nilai viskositas suspensi bubuk okara dengan perlakuan hidrotermal (HT) cenderung lebih rendah daripada yang tanpa perlakuan hidrotermal (OR). Bubuk okara yang dihasilkan dalam studi ini memiliki kapasitas penyerapan air lebih besar daripada penyerapan minyak

\section{DAFTAR PUSTAKA}

Association of Official Analytical Chemists (AOAC). 1999. Official Method of Analysis. Association of Official Analytical Chemist. Washington DC.
Askar, A., Treptow, H. 1993. Physical measurements. In: Quality Assurance in Tropical Fruit Processing. Springer Laboratory. Springer, Berlin, Heidelberg. pp 46-47. DOI: 10.1007/978-3-642-77687-8_3.

Benoit, S.M., Afizah, M.N., Ruttarattana mongkol, K., Rizvi, S.S.H. 2013. Effect of $\mathrm{pH}$ and temperature on the viscosityof texturized and commercial whey protein dispersions. International Journal of Food Properties, 16 (2): 322-330. DOI:10.1080/ 10942912.2011.552015.

Chang, M.C., Morris, W.C. 1990. The effect of heat treatments on dietary fiber as assessed by scaning electron microscopy. Journal of Food Processing and Preservation, 14 (5): 335-343. DOI:10.1111/j.17454549.1990.tb00138.x.

Egan H., Kirk, R.S., Sawyer, R. 1987. Pearsons Chemical Analysis of Food 8th Ed. Longman Scientific and Technical

Fellows, P. 1988. Food Processing Technology: Principles and Practice. Ellis Horwood.

Kinsella, J.E. 1982. Relationship between structure and functional properties of food protein. in Food Protein, Ed. Fox PF. and Condon JJ., Applied Sci., NY pp 51-103.

Li, B., Qiao, M., Lu, F. 2012. Composition, nutrition, and utilization of okara (soybean residue). Food Reviews International, 28.(3): 231-252. DOI: 10.1080/87559129. 2011.595023.

Lu, J.Y., Al Jasser, M.S. 1986. Characteristics and acceptability of a flour prepared from sodium bicarbonate soaked and steamed soybeans. Journal of Food Processing and Preservation, 10.(3): 177-187. DOI: $10.1111 / \mathrm{j} .1745-$ 4549.1986.tb00017.x.

Lu, F., Cui, Z., Liu, Y., Li, B. 2013. The effect of okara on the qualities of noodle and steamed bread. Advance Journal of Food Science and Technology, 5.(7): 960-968. DOI: 10.19026/ajfst.5.3191. 
Ma, C.Y., Liu, W.S., Kwok, K.C., Kwok, F. 1997. Isolation and characterization of protein from soymilk residue. Food Research International, 29 (8): 799-805. DOI: 10.1016/0963-9969(95)00061-5.

Mohsenin, N.N. 1986. Physical Properties of Plant and Animal Materials. Gordon and Beach Sci. Publisher, NY.

Nguyen, D.Q., Mounir, S., Allaf, K. 2015. Functional properties of water holding capacity, oil holding capacity, wettability, and sedimentation of swelldried soybean powder. Scholars Journal of Engineering and Technology, 3 (4B): 402-412. DOI: 10.21276/sjet.

Perussello, C.A., Amarante, A.C.C., Mariani, V.C. 2009. Convective drying kinetics and darkening of okara. Drying Technology, 27 (10): 1132-1141. DOI: 10.1080/07373930903221622.

Porcel, M.V.O., Panelo, N.Q., Rinaldoni, A.N., Campderrós, M.E. 2017. Incorporation of okara into gluten-free cookies with high quality and nutritional value. Journal of the Science of Food and Agriculture, 97 (9): 2934-2941. DOI: $10.1002 /$ jsfa.8131.

Shurtleff, W., Aoyagi, A. 2000. Tofu and Soymilk Production: A Craft and Technical Manual, Soyfood Center, 115131.

Taruna, I. 2006. Karakteristik mutu tepung ampas tahu hasil pengeringan metode spouted vortex bed. Prosiding Seminar Nasional PATPI 2006. UGM Yogyakarta, 2-3 Agustus 2006.

Traina, M.S., Breene, W.M. 1994. Composition functionality and some chemical and physical properties of eight commercial full-fat soy flour. Journal of Food Processing and Preservation, 18(3): 229-252. 4549.1994. tb00846.x

Turhan, S., Temiz, H., Sagir, I. 2009. Characteristics of beef patties using okara powder. Journal of Muscle Foods, 20 (1): 89-100. DOI:10.1111/j.1745-45 73.2008. 00138.x.
Zhong, Y., Zhao, Y. 2015. Chemical composition and functional properties of three soy processing by-products (soy hull, okara and molasses). Quality Assurance and Safety of Crops \& Foods, 7 (5): 651-660. DOI:10.3920/QAS2014. 0481 . 